\title{
The Mediator Role of Interaction Anxiety in the Relationship between Social Support Perception and Smartphone Addiction
}

\begin{tabular}{ccc}
\hline Article Type & Received Date & Accepted Date \\
Research & 21.02 .2018 & 05.09 .2018 \\
\hline
\end{tabular}

Necdet Konan**

\section{O. Tayyar Çelik ${ }^{* * *}$}

\begin{abstract}
Preservice teachers prepare for a profession that requires intense communication and interaction. They are expected to gain competencies in their profession in this process. These competencies include the technical knowledge particular to the profession, and communication and social skills. It is thus important to investigate the factors that affect the academic and social interaction, the learning environment and the psycho-social development of university students, and in particular, preservice teachers. This study aims to investigate the relationship among preservice teachers' social support perceptions, interaction anxiety and smartphone addiction. The students from the faculty of education and the students with the pedagogical formation training in İnönü University during the 2017-2018 academic year constituted the population of the study and the participants were 496 preservice teachers who were selected from this population using the random sampling technique. Hypotheses were developed to investigate the relationship among the research variables. After testing the hypotheses, the results indicated that the preservice teachers' social support perceptions and interaction anxiety significantly predicts their smartphone addiction, that their social support perceptions significantly predict their interaction anxiety, and that their interaction anxiety has a mediator effect on the relationship between their social support perceptions and smartphone addiction.
\end{abstract}

Keywords: Social support perception, interaction anxiety, smartphone addiction, preservice teachers.

\footnotetext{
${ }^{*}$ This study was partly presented at the $9^{\text {th }}$ IX International Congress of Education Supervision in Antalya. Turkey, 01-03 November, 2017.

** Prof. Dr., Inonu University, Faculty of Education, Department of Educational Sciences, Malatya, Turkey. E-mail: necdet.konan@inonu.edu.tr, https://orcid.org/0000-0001-6444-9745

*** Corresponding Author: PhD. Pamukkale University, Denizli, Turkey. E-mail: otayyar44@ gmail.com, https://orcid.org/0000-0003-3951-7261
} 


\title{
Sosyal Destek Algısı ve Akıllı Telefon Bağımlılığı İlişkisinde Etkileşim Kaygısının Aracılık Rolï*
}

\begin{tabular}{ccc}
\hline Makale Türü & Başvuru Tarihi & Kabul Tarihi \\
Araştırma & 21.02 .2018 & 05.09 .2018 \\
\hline
\end{tabular}

Necdet Konan**

\author{
O. Tayyar Çelik****
}

\section{$\ddot{O} \mathbf{z}$}

\begin{abstract}
İletişim ve etkileşimin yoğun olduğu bir mesleğe hazırlanan öğretmen adaylarından, bu süreç içerisinde meslekleriyle ilgili yeterlikleri kazanmaları beklenmektedir. Bu yeterlikler içerisinde, mesleğe ve alanlarına özgü teknik bilgilerin yanında iletişim ve sosyal becerileriler de yer almaktadır. Bu kapsamda üniversite öğrencilerinin, özelde ise öğretmen adaylarının akademik ve sosyal entegrasyonunu, öğrenme çevrelerini ve piko-sosyal gelişimlerini etkileyen çeşitli faktörlerin araştırılması önem kazanmaktadır. Bu araştırmada, öğretmen adaylarının sosyal destek algılarıyla etkileşim kaygıları ve akıllı telefon bağımlılıkları arasındaki ilişkiyi incelemek amaçlanmıştır. Araştırmanın evrenini 2017-2018 eğitim-öğretim yılında İnönü Üniversitesinde eğitim görmekte olan eğitim fakültesi öğrencileri ve pedagojik formasyon eğitimi alan öğrenciler, örneklemini ise bu evrenden seçkisiz örnekleme yöntemiyle belirlenen 496 öğretmen aday1 oluşturmaktadır. Araştırma değişkenleri arasındaki ilişsilere yönelik denenceler oluşturulmuştur. Denencelerin sınanması sonucunda öğretmen adaylarının sosyal destek algılarının ve etkileşim kaygılarının akıllı telefon bağımlılıklarını anlamlı bir şekilde yordadığı, sosyal destek algılarının etkileşim kaygılarını anlamlı bir şekilde yordadığı, sosyal destek algılarıyla akıllı telefon bağımlılıkları arasındaki ilişkide etkileşim kaygılarının aracılık etkisi olduğu sonuçlarına ulaşılmıştır.
\end{abstract}

Anahtar Sözcükler: Sosyal destek algıS1, etkileşim kaygısı, akıllı telefon bağımlılığı, öğretmen adayı.

\footnotetext{
* Bu çalışma, 01-03 Kasım 2017 tarihinde Antalya/Türkiye'de gerçekleştirilen IX. Uluslararası Eğitim Denetimi Kongresinde sözlü bildiri olarak sunulmuştur.

** Prof. Dr., İnönü Üniversitesi, Eğitim Fakültesi, Eğitim Bilimleri Bölümü, Malatya, Türkiye.

E-posta: necdet.konan@inonu.edu.tr, https://orcid.org/0000-0001-6444-9745.

*** Dr. Öğr. Gör., Pamukkale Üniversitesi, Denizli, Türkiye. E-posta: otayyar44@gmail.com, https://orcid.org/0000-00033951-7261.
} 


\section{Introduction}

One of the most important characteristics that separate humankind with skills of foreseeing the future and making plans for the future from other living things is their ability to transform their information into technologies that facilitate their lives. Artificial intelligence has been discussed today where rapid changes in technology have been experienced and it is predicted that artificial intelligence will take place in several areas of our lives in near future. In fact, we have already begun to describe many of the technological tools we use as "smart." The advancements in the information and communication technologies underlie the technological advancements. Constantly and rapidly updated, information and communication technologies have considerably changed our lifestyles and become an inseparable part of our lives (Salehan \& Nagehban, 2013).

As technologies have changed rapidly, they have become more practical and smaller. Smartphones have become an indispensable part of the lives of people in all age groups (Takao, Takahashi \& Kitamura, 2009). Smartphones not only take the place of phones, but also personal computers and other tools to some extent (Salehan \& Nagehban, 2013; Samaha \& Hawi, 2016). Beyond having the features of making phone calls and sending messages, smartphones can be used to access the internet, send e-mails, provide navigation services, share pictures and videos, play music, watch films, download games, participate in social media, shop and manage finances (Gökçearslan, Mumcu, Haşlaman \& Çevik, 2016; Kuyucu; 2017; Sapacz, Rockman \& Clark, 2016).

As well as the advantages of being lightweight and compact enough to fit easily into a bag or pocket (Elhai, Dvorak, Levine \& Hall, 2017), smartphones also have disadvantages (Çakır \& Oğuz, 2017; Park, 2005). In particular, their gradual elimination of temporal and spatial limitations and the uncontrolled increase in obsessive use of them have led to coining the term, smartphone addiction (AlBarashdil, Bouazza \& Jabur, 2015; Hong, Chiu \& Huang, 2012; Lepp, Barkley \& Karpinski, 2014; Park, 2005; Park \& Lee, 2012; Samaha \& Hawi, 2016). Even though smartphone addiction is described in different ways such as problematic mobile phone use, excessive use and obsessive use (Kardefelt \& Winther, 2014; Kim \& Byrne, 2011), all these descriptions indicate a form of overuse that causes individuals to neglect other areas of life (Barashdil et al., 2015).

Smartphone addiction refers to obsessive smartphone use that is difficult to control and negatively affects other areas of life (Park \& Lee, 2012). Many researchers considered the smartphone addiction as a behavioral addiction in the context of obsessively exhibiting a behavior (Lemon, 2002; Takao et al., 2009). Smartphone addicts are likely to exhibit these behaviors (Lee, Chang, Lin \& Cheng, 2014):

1) Always being busy with the phone,

2) Increasing phone use to get satisfaction from the phone,

3) Failing to stop, pause or attempt to control using the phone,

4) Feeling discomfort about attempts to reduce phone use,

5) Jeopardizing important relationships, and education and career opportunities due to the phone use,

6) Using the smartphone as a tool to alleviate hearing problems, depression, anxiety and, hopelessness.

Addiction can cause great harm to society and individuals by affecting work and learning (Park, 2005). The fact that smartphones are always accessible distinguishes this addiction from other addiction types, and this addiction is a threat to individuals and society (Kahyaoğlu-Süt, Kurt, Uzal \& Özdilek, 2016). Such behavioral addictions have not only side effects (Yen et al., 2009), but also psychological and physical effects such as hand and neck pain, sleep problems and visual disorders (Kuyucu, 2017). Studies of adolescents and university students' smartphone addiction have reported: that problematic phone use is a function of an extrovert personality type (Salehan \& Nagehban, 2013), that there are significant relationships between smartphone addiction and negative emotions (Chen et al., 2016), that social extroversion and anxiety increase smartphone addiction (Hong et al., 2012), that 
smartphone addiction negatively affects academic performance (Jacobsen \& Forste, 2011; Samaha \& Hawi, 2016; Seo, Park, Kim \& Park, 2016), and that smartphone addiction can cause depression and anxiety, which in turn can result in sleep disorders (Demirci, Akgönül \& Akpınar, 2015).

These results indicate that smartphone addiction negatively affects individuals' personal and social lives. Therefore, it is of critical importance to investigate smartphone use, which is particularly common among university students, with the risk of turning into an addiction that can negatively affect their social, professional and academic performance and to examine the factors that affect their smartphone use. This study investigated the relationship of preservice teachers' smartphone addiction, which was reported to affect university students' personal, social, and academic development, with their social support perception and interaction anxiety.

\section{Relationship between Social Support Perception and Smartphone Addiction}

Social support is defined as the social support behaviors that individuals receive from other individuals and social networks (Heller, Swindle \& Dusenbury, 1986). Yıldırım (1997) defined social support as the social and psychological support individuals obtain from their environment. The accessibility of supporting individuals and the personal satisfaction obtained from real support are two important dimensions of perceived social support (Kitamura, Watanabe Takezaki \& Tanaka, 1999), and the satisfaction obtained from a social support rather than its quantity is determinative for individuals.

Social support perception has mental and physical benefits (Cohen \& Wills, 1985). Social support is a human need because people are social beings. The perception of this need being met has positive effects on individuals. Stress, anxiety and addictive behaviors are more common for people who lack support and feel lonely. Studies have reported a significant relationship between smartphone addiction, which is considered a behavioral addiction, and loneliness (Caplan, 2006; Çakır \& Oğuz, 2017; Şar, 2013; Tan, Pamuk \& Döner, 2013). Social isolation, which is closely related to social support perception, stems from inadequate relationships in social networks or the inability to become a member of a social network in which similar interests or activities are shared. This problem can be eliminated by accessing an environment where individuals can reach satisfaction (Çakır \& Oğuz, 2017). Social isolation causes behavioral addictions such as internet and smartphone addiction. A relationship that is similar to the one between loneliness and the smartphone addiction is thought to be present between social support perception and smartphone addiction. The lack of support is one of the sources of individuals' sense of loneliness. Based on the relevant theoretical information and the results of studies, this study's hypothesis is that preservice teachers' social support perceptions significantly predict their smartphone addiction in a negative way.

\section{The Relationship between Social Support Perception and Interaction Anxiety}

Social anxiety is the behavioral tendency to withdraw from social interactions due to internal conflict or excessive fear (Rubin, Coplan \& Bowker, 2009). In DSM 5, social anxiety disorder is defined as evident persistent fear that emerges in social settings, situations requiring a performance, or in front of unknown people (American Psychiatry Association, 2013).

Studies investigating the relationship between the social support perception and interaction anxiety (Baltac1, 2010; Baltacı, İşleyen \& Özdemir, 2012; Huber, 2016) reported that individuals' social anxiety level increases as their support perception decreases. It was also put forward that the social support perception has mental and physical benefits (Cohen \& Wills, 1985). Therefore, it can be asserted that individuals receiving enough support from their social environment can establish meaningful relationships, less experience psychological problems, or are able to overcome such problems more quickly. Individuals' social support sources can be investigated in order to reveal the relationship between the social support perception and interaction anxiety.

Based on the relevant theoretical information and the results of studies, this study's hypothesis is that preservice teachers' social support perceptions significantly predict their interaction anxiety in a negative way. 


\section{The Relationship between Interaction Anxiety and Smartphone Addiction}

According to Lee et al. (2014), social interaction anxiety and the need for interaction increase the need for phone use and the pressure to use. This relationship also increases trust in smartphones. In other words, smartphones can be used a tool to meet individuals' need for interaction. Interaction with smartphones is less sincere than face-to-face interaction. This difference can decrease anxiety during interaction with others since it enables people to think more about every reply in a conservation. King et al. (2013) found that smartphones can make individuals with social anxiety to feel safe in social settings. Individuals use smartphones to interact with others due to lack of trust and shyness in faceto-face communication (Walsh, White \& Young, 2007). Barashdil et al. (2015) found that smartphones with various features can serve as an effective way for shy students to communicate with others.

Many studies of this issue have highlighted a significant relationship between social anxiety and smartphone addiction (Bianchi \& Phillips, 2005; Elhai et al., 2017; Lepp et al., 2014; Sapacz et al., 2016; Y1lmaz, Car \& Şivan, 2015). On the other hand, some studies found no significant relationship between these variables (Harwood, Dooley, Scott \& Joiner, 2014; Whiteside \& Lynam, 2001).

Based on the relevant theoretical information and the results of studies, this study's hypothesis is that preservice teachers' interaction anxiety significantly predicts their smartphone addiction in a positive way.

\section{The Mediator Effect of Interaction Anxiety}

The previous sections discussed the relationship among the research variables and indicated a strong relationship between interaction anxiety and smartphone addiction. The results of this study suggest that interaction anxiety has a mediator effect, which is also closely related to social support perception and smartphone addiction. Many studies have indicated that social support perception can serve as a buffer to prevent the development of anxiety, depression and loneliness (Rubin et al., 2006; Terzi, 2008). Behaviors that can be described as addiction are particularly common in individuals with psychological problems.

Based on relevant theoretical information and the results of studies, this study's hypothesis is that preservice teachers' interaction anxiety has a mediator effect on the relationship between their social support perceptions and smartphone addiction.

\section{The Purpose and Importance of the Study}

Studies have shown that the smartphone addiction has important effects on university students' academic achievement, personal lives and social interactions. High-level smartphone addiction has been reported to decrease university students' level of self-regulation in learning, to influence their study flow negatively, to prevent their academic studies, to cause them to be busy with other activities while studying and to decrease their academic performance (Lee, Cho, Kim \& Noh, 2015).

Preservice teachers prepare for a profession that requires intense communication and interaction. They are expected to gain competencies in their profession in this process. These competencies include the technical knowledge particular to the profession, and communication and social skills. It is thus important to investigate the factors that affect the academic and social interaction, the learning environment and the psycho-social development of university students, and in particular, preservice teachers. This study aimed to investigate the relationships among preservice teachers' social support perception, interaction anxiety and smartphone addiction.

\section{Method}

This study was designed as a relational survey. Relational survey is a research method that aims to investigate the presence and/or the degree of covariance between two or more variables (Cohen, Manion \& Morrison, 2007; Fraenkel \& Wallen, 2003).

Based on the theoretical knowledge and the results of similar studies, hypotheses about the relationship among the preservice teachers' social support perceptions, interaction anxiety, and smartphone addiction were developed, and a model was proposed. The model is shown in Figure 1. 


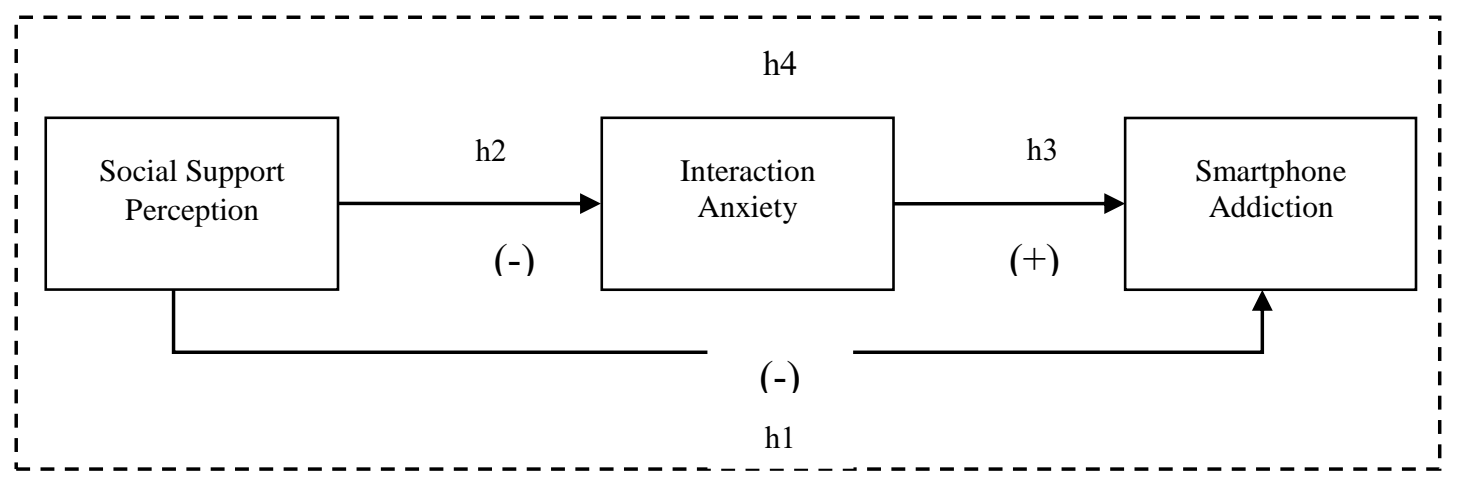

Figure 1. The Proposed Model

Hypothesis 1 (hl): Preservice teachers' social support perceptions significantly predict smartphone addiction in a negative way.

Hypothesis 2 (h2): Preservice teachers' social support perceptions significantly predict their interaction anxiety in a negative way.

Hypothesis 3 (h3): Preservice teachers' interaction anxiety significantly predicts their smartphone addiction in a positive way.

Hypothesis 4 (h4): Preservice teachers' interaction anxiety has a mediator effect on the relationship between their social support perceptions and smartphone addiction.

\section{Research Sample}

The students in the faculty of education and pedagogical formation training at İnönü University during the 2017-2018 academic year constituted the population of the study. The participants were 496 preservice teachers who were selected from this population using random sampling.

Of the participants, $75.4 \%$ (374) were female, and $24.6 \%$ (122) were males. Of them, $23.6 \%$ were in the faculty of education, and $76.4 \%$ were in pedagogical formation training.

\section{Research Instruments and Procedures}

In addition to a personal information form, the following scales were used in the study:

\section{The smartphone addiction scale-short form (SAS-SF)}

Developed by Kwon et al., (2013) and adapted into Turkish by Noyan, Enez Darçın, Nurmedov, Y1lmaz and Dilbaz (2015), this scale consists of 10 six-point Likert-type items and a single-factor structure. Scores on the scale range from 10 to 60. Higher scores indicate increased the risk of addiction. Noyan et al. (2015) found the Cronbach's alpha coefficient of the scale to be .86 . The Cronbach's alpha coefficient of the scale was .91 in this study.

\section{The interaction anxiety Scale (IAS)}

The scale was developed by Leary and Kowalski (1993) and adapted into Turkish by Coşkun (2009). It consists of 15 five-point Likert-type items. It has a single-factor structure, and items 2, 3, 6 , 10 and 15 are scored reversely. High scores on the scale indicate increased social interaction anxiety. Coşkun (2009) found the Cronbach's alpha coefficient of the scale to be .91. The Cronbach's alpha coefficient of the scale was .88 in this study.

\section{The multidimensional scale of perceived social support (MSPSS)}

Developed by Zimet et al. (1988, 1990), and adapted into Turkish by Eker, Arkar, and Yadiz (2001), this scale consists of 12 seven-point Likert-type items. Higher scores on the scale indicate 
stronger perceived social support. While Eker et al. (2001) found the Cronbach's alpha coefficient of the scale to be .89 , it was .85 in this study.

\section{Data Analysis}

Descriptive statistics, correlation analysis, simple linear regression analysis, hierarchical regression analysis and the Sobel test were used to analyze the data. Prior to the analyses, the univariate and multivariate normality assumptions were investigated.

Within the scope of the univariate normality assumptions, the skewness and kurtosis coefficients were calculated. Coefficient values between -1 and +1 indicate a normal distribution (Çokluk, Şekercioğlu \& Büyüköztürk, 2012). Within the scope of the multivariate normality, the tolerance and VIF values were investigated. A VIF value less than 10 and a tolerance value greater than 0.2 indicated that there was no multiple linear correlation (Field, 2005; Can, 2014). The results of these tests are shown in Table 1.

\section{Table 1}

The Skewness, Kurtosis, Tolerance and Vif Values of the Research Variables

\begin{tabular}{lllll}
\hline Variable & Skewness & Kurtosis & Tolerance & VIF \\
\hline Social Support Perception & $-0,118$ & 0,241 & 0,47 & 4,88 \\
Interaction Anxiety & 0,262 & $-0,565$ & 0,51 & 3,99 \\
Smartphone Addiction & $-0,618$ & -752 & 0,36 & 5,72 \\
\hline
\end{tabular}

Table 1 shows that the skewness and kurtosis values were within the range of the limit values ($1,+1)$, and that no multiple linear correlation was found among the research variables according to the tolerance $(>.02)$ and VIF (<.10) values. The normality assumptions for conducting the analyses were met.

\section{Results}

This section presents the results of the descriptive analyses of the preservice teachers' social support perception, interaction anxiety and smartphone addiction, and the results of testing this study's hypotheses.

\section{Results for Descriptive Statistics}

Write down the results about the research question without changing the format. Write down the results about the research question without changing the format.

The descriptive statistics results for the preservice teachers' social support perception, interaction anxiety and smartphone addiction are shown in Table 2.

Table 2

Descriptive Statistics Results for the Research Variables

\begin{tabular}{|c|c|c|c|c|c|c|c|}
\hline Variable & $\mathbf{X}$ & SD & Minimum & Maximum & 1 & 2 & 3 \\
\hline 1. Social Support Perception & 63,88 & 3,46 & 7 & 84 & - & & \\
\hline 2. Interaction Anxiety & 41,38 & 5,12 & 15 & 75 & $-.344 * *$ & - & \\
\hline 3. Smartphone addiction & 27,98 & 2,21 & 10 & 60 & $-.136 * *$ & $.251 * *$ & - \\
\hline
\end{tabular}

Table 2 shows that the preservice teachers had higher than moderate levels of social support perceptions $(X=63.88)$, and that they had moderate levels of interaction anxiety $(X=41.38)$ and smartphone addiction $(X=27.98)$. The results for the relationship among the variables indicated a negative significant relationship between the preservice teachers' social support perceptions and smartphone addiction $(\mathrm{r}=-.13, \mathrm{p}<.01)$, a negative significant relationship between their social support 
perceptions and interaction anxiety $(\mathrm{r}=-.34, \mathrm{p}<.01)$, and a positive significant relationship between their interaction anxiety and smartphone addiction $(r=.25, \mathrm{p}<.01)$.

\section{Results for the Hypotheses of the Study}

Simple linear regression analysis was conducted to test the first, second and third hypotheses of the study. Hierarchical regression analysis was used to test the fourth hypothesis about the mediator effect.

\section{Results for the first hypothesis of the study}

The first hypothesis of the study was that preservice teachers' social support perceptions significantly predict their smartphone addiction in a negative way. The results of the simple linear regression analysis carried out to test this hypothesis are shown in Table 3.

Table 3

Regression Analysis Results for Social Support Perception's Prediction of Smartphone Addiction

\begin{tabular}{lccccc}
\hline Variable & B & S. Error & $\boldsymbol{\beta}$ & t & Sig. \\
\hline Constant & 34.818 & 2.298 & & 15,154 & .000 \\
Social Support Perception & -0.107 & 0.035 & -0.136 & -3.048 & .002 \\
\hline $\mathrm{R}=.13$, & & & & & \\
$\mathrm{F}(1.494)=9.290, \mathrm{P}=.002$ & & & & & \\
\hline
\end{tabular}

Table 3 shows that the preservice teachers' social support perceptions significantly predicted their smartphone addiction in a negative way $(\beta=-.136, \mathrm{p}<.05)$. Based on these results, the first hypothesis of the study was confirmed, and the preservice teachers' social support perception was found to have a significant effect on their smartphone addiction.

\section{Results for the second hypothesis of the study}

The second hypothesis of the study was that the preservice teachers' social support perceptions significantly predict their interaction anxiety in a negative way. The results of the simple linear regression analysis carried out to test this hypothesis are shown in Table 4.

\section{Table 4}

Regression Analysis Results for Social Support Perception's Prediction of Interaction Anxiety

\begin{tabular}{lccccc}
\hline Variable & B & S. Error & $\boldsymbol{\beta}$ & t & Sig. \\
\hline Constant & 55.706 & 1.801 & & 30.93 & .000 \\
Social Support Perception & -0.136 & 0.028 & -0.344 & -8.142 & .000 \\
\hline $\mathrm{R}=.34, \quad \mathrm{R} 2=.11$ & & & & & \\
$\mathrm{~F}(1.494)=66.299, \mathrm{P}=.000$ & & & & & \\
\hline
\end{tabular}

Table 4 shows that the preservice teachers' social support perceptions significantly predicted their interaction anxiety in a negative way $(\beta=-.344, p<.05)$. Based on these results, the second hypothesis of the study was confirmed, and the preservice teachers' social support perception was found to have a significant effect on their interaction anxiety.

\section{Results for the third hypothesis of the study}

The third hypothesis of the study was that preservice teachers' interaction anxiety significantly predicts their smartphone addiction in a positive way. The results of the simple linear regression analysis carried out to test this hypothesis are shown in Table 5. 


\section{Table 5}

Regression Analysis Results for Interaction Anxiety's Prediction of Smartphone Addiction

\begin{tabular}{lllllc}
\hline Variable & B & S. Error & $\boldsymbol{\beta}$ & t & Sig. \\
\hline Constant & 15.395 & 2.23 & & 6.903 & .000 \\
Interaction anxiety & 0.304 & 0.053 & 0.251 & 5.775 & .000 \\
\hline
\end{tabular}

$\mathrm{R}=.25, \quad \mathrm{R} 2=.06$

$\mathrm{F}(1.494)=33.352, \mathrm{P}=.000$

As Table 5 shows, the preservice teachers' interaction anxiety significantly predicted their smartphone addiction in a positive way $(\beta=.251, \mathrm{p}<.05)$. Based on these results, the third hypothesis of the study was confirmed, and the preservice teachers' interaction anxiety was found to have a significant effect on their smartphone addiction.

\section{Results for the fourth hypothesis of the study}

The fourth hypothesis of the study was that preservice teachers' interaction anxiety has a mediator effect on the relationship between their social support perceptions and smartphone addiction. In order to mention a mediator effect of a third variable in the relationship between two variables, the following conditions should be met (Baron \& Kenny, 1986; Karagöz, 2016):

1) The independent variable should have an effect on the dependent variable.

2) The independent variable should have an effect on the mediator variable.

3) The mediator variable should have an effect on the dependent variable.

4) When the mediator variable is included in the model along with the independent variable, the effect of the independent variable on the dependent variable should decrease, while the effect of the mediator variable on the dependent variable should be significant.

Under these conditions, it was determined that the independent variable (social support perception) had a significant effect on the dependent variable (smartphone addiction) (Table 4), that the independent variable (social support perception) had a significant effect on the mediator variable (interaction anxiety) (Table 5), and that the mediator variable has a significant effect on the dependent variable (Table 6).

Hierarchical regression analysis was conducted to test the fourth condition. The results are shown in Table 6.

Table 6

Hierarchical Regression Analysis Results for Smartphone Addiction

\begin{tabular}{llccccc}
\hline Steps & & B & S. Error & $\boldsymbol{\beta}$ & t & sig. \\
\hline \multirow{2}{*}{ 1. Step } & Constant & 34.818 & 2.298 & & 15.154 & .000 \\
& Social Support Perception & -0.107 & 0.035 & -0.136 & -3.048 & .002 \\
\multirow{3}{*}{ Step } & Constant & 19.18 & 3.845 & & 4.988 & .000 \\
& Social Support Perception & -0.04 & 0.037 & -0.06 & -1.21 & .228 \\
& Interaction Anxiety & 0.281 & 0.056 & 0.232 & 5.01 & .000 \\
\hline
\end{tabular}

Table 6 shows that when interaction anxiety, the mediator variable, was included in the model in the second step, the standardized regression coefficient of the social support variable decreased significantly $(\beta=-0.6, p>.05)$, and the effect of social support perception on the smartphone addiction became insignificant. The significance of the decrease in the standardized regression coefficient was investigated using the Sobel test. The results of the test indicated that the mediator effect is significant $(\mathrm{Z}=4.41891 \mathrm{p}<.001)$. It was also determined that interaction anxiety affected smartphone addiction $(\beta=.232, p<.05)$. The literature interprets the disappearance of the independent variable's significant effect as a full mediator effect (Baron \& Kenny, 1986; Holmbeck, 1997). In this case, the interaction 
anxiety played a full mediator role in the relationship between social support perception and smartphone addiction.

These results indicate all the conditions for the mediator effect were met. Therefore, the hypothesis indicating that preservice teachers' interaction anxiety has a mediator effect on the relationship between their social support perceptions and smartphone addiction was confirmed.

\section{Discussion, Conclusion and Recommendations}

The results of the study indicated that the preservice teachers had higher than moderate levels of social support perception and moderate levels of interaction anxiety $(X=41.38)$ and smartphone addiction $(\mathrm{X}=27.98)$. All of the hypotheses based on theoretical knowledge and the results of similar studies were confirmed.

In the study, the preservice teachers' social support perceptions were found to significantly predict their smartphone addiction in a negative way. Even though there is a limited number of studies in the literature that focus on the relationship between social support perception and smartphone addiction, studies of the relationship between loneliness and smartphone addiction (Çakır \& Oğuz, 2017; Öztunç, 2013; Reid, 2007) have highlighted significant relationships between these two variables. Taşdemir (2016) found that students' levels of internet addiction increase as their loneliness levels increase, and that their loneliness levels increase as their levels of social support perception decrease. Low levels of social support perceived by individuals can be regarded as a source of loneliness. Addictive behaviors are more common in individuals with low levels of social support perception, as in the sense of loneliness. This study's results are consistent with those of other studies in the literature.

Another result of the study is related to the relationship between social support perception and their interaction anxiety, and indicated that the preservice teachers' social support perceptions significantly predict their interaction anxiety in a negative way. This result is consistent with those of similar studies (Baltac1, 2010; Baltac1, et al., 2012). Individuals who receive enough support from the social environment have a wider social environment. Individuals social support resources increase as their social environment enlarges. Therefore, it becomes more likely for them to get support when they need it, and the significant effect of social support perception on the interaction anxiety is an expected result.

The results of the study indicated that the preservice teachers' interaction anxiety significantly predicted their smartphone addiction. Various studies have found similar results (Bianchi \& Phillips, 2005; Elhai et al., 2017; Lepp et al., 2014; Y1lmaz et al., 2015). In particular, shy and socially anxious individuals tend to meet their social needs with mediators. They feel safe in this way, and smartphones become an important tool that fulfills this mediator function. This situation can cause smartphone addiction in individuals with interaction anxiety.

The analyses of the mediator effect found a full mediator role of the preservice teachers' interaction anxiety in the relationship between their social support perceptions and smartphone addiction. It is noteworthy that no studies were found in the literature that investigates the mediator effect of interaction anxiety in the relationship between preservice teachers' social support perception and smartphone addiction.

It is clear that interaction anxiety, which has a significant relationship with both social support perception and smartphone addiction, has a mediator effect, as this study confirmed. This result can be interpreted to mean that the preservice teachers' low social support perceptions affect their interaction anxiety, thereby increasing their smartphone addiction levels. In this case, preservice teachers' smartphone addiction is a result of their interaction anxiety, rather than a result of their social support perceptions.

The teaching profession requires particular knowledge and skills, and preservice teachers are expected to acquire them during their education. However, the results of the study show that physical and mental health as well as smartphone addiction negatively affect their academic performance. It should be considered that the frequency and level of smartphone use of preservice teachers being 
trained for a profession that requires excellent communication and social interaction skills may also have the risk of turning into a source of problems in their profession.

Based on the results of this study, the researchers recommend:

1) Providing preservice teachers with seminars regarding self-regulation can be beneficial in smartphone use and time management.

2) Preservice teachers should be informed about the physical and psychological effects of smartphone use.

3) Activities such as anxiolytic or preventive therapy should be held individually or collectively for preservice teachers with interaction anxiety.

4) Preservice teachers should be helped to form supportive environments. When needed, activities such as peer guidance, group activities and orientations should be organized.

5) With activities to be carried out during the learning process, preservice teachers should establish good relationships with their immediate environment (family and relatives) and their social environments (friends and activity groups), and these relationships will reduce their interaction anxiety.

\section{References}

Al-Barashdi, H. S., Bouazza, A., \& Jabur, N. H. (2015). Smartphone addiction among university undergraduates: a literature review. Journal of Scientific Research \& Reports, 4(3), 210-225.

American Psychiatric Association. (2013). Diagnostic and statistical manual of mental disorders: DSM-5. Washington, D.C: American Psychiatric Association.

Baltac1, Ö. (2010). Üniversite öğrencilerinin sosyal kaygl, sosyal destek ve problem çözme yaklaşımlarl arasindaki ilişkinin incelenmesi. [Examining the relationship between university students' social anxiety, social support and problem-solving approach]. (Unpublished Master Thesis), Selçuk University, Institute of Educational Sciences, Konya.

Bianchi, A., \& Phillips, J. G. (2005). Psychological predictors of problem mobile phone use. CyberPsychology \& Behavior, 8(1), 39-51.

Can, A. (2014). SPSS ile bilimsel araştırma sürecinde veri analizi [Data analysis in scientific research process with SPSS]. Ankara: Pegem Academy Publishing.

Cohen, S., \& Wills, T. A. (1985). Stres, social support and the buffering hypothesis. Psyhological Bulletin, 98(2), 310-357.

Cohen, L., Manion, L., \& Morrison, K. (2007). Research methods in education. New York, NY, US: Routledge/Taylor \& Francis Group.

Coşkun, H. (2009). Etkileşim kaygısı ölçeği: geçerlik ve güvenirlik çalışması [Interaction anxiety scale: validity and reliability study]. Türk Psikoloji Yazılart [Turkish Psychological Articles], 12(23), 41-49.

Çakır, Ö., \& Oğuz, E. (2017). Lise öğrencilerinin yalnızlık düzeyleri ile akıllı telefon bağımlılı̆̆ı arasındaki ilişki [The correlation between high school students' loneliness levels and smart phone addiction]. Mersin Üniversitesi Eğitim Fakültesi Dergisi [Mersin University Journal of the Faculty of Education], 31(1), 418-429.

Çokluk, Ö., Şekercioğlu, G. \& Büyüköztürk, Ş. (2012). Sosyal bilimler için çok değişskenli istatistik SPSS ve LISREL uygulamalar [SPSS and LISREL applications of multivariate statistics for social sciences]. Ankara: Pegem Academy Publishing.

Demirci, K., Akgönül, M., \& Akpinar, A. (2015). Relationship of smartphone use severity with sleep quality, depression, and anxiety in university students. Journal of behavioral addictions, 4(2), 85-92.

Eker, D., Arkar, H. \& Yaldız, H. (2001). Çok boyutlu algılanan sosyal destek ölçeğinin gözden geçirilmiş formunun faktör yapısı, geçerlik ve güvenirliği [Factorial structure, validity, and reliability of revised form of the multidimensional scale of perceived social support]. Türk Psikoloji Yazıları [Turkish Psychological Articles], 12(1), 17-25. 
Elhai, J. D., Dvorak, R. D., Levine, J. C., \& Hall, B. J. (2017). Problematic smartphone use: A conceptual overview and systematic review of relations with anxiety and depression psychopathology. Journal of affective disorders, 207, 251-259.

Field. A. (2005). Discovering statistics using SPSS. Londan: Sage Publications.

Fraenkel, J.R., \& Wallen, N.E. (2003). How to design and evaluate research in education. New York: McGraw-Hill Companies, Inc.

Gökçearslan, Ş., Mumcu, F. K., Haşlaman, T., \& Çevik, Y. D. (2016). Modelling smartphone addiction: The role of smartphone usage, self-regulation, general self-efficacy and cyberloafing in university students. Computers in Human Behavior, 63, 639-649.

Harwood, J., Dooley, J. J., Scott, A. J., \& Joiner, R. (2014). Constantly connected-The effects of smart-devices on mental health. Computers in Human Behavior, 34, 267-272.

Heller, K., Swindle, R. W., \& Dusenbury, L. (1986). Component social support processes: Comments and integration. Journal of Consulting and Clinical Psychology, 54(4), 466.

Huber, L. (2016). The role of social support and self-concept in victimization and social anxiety in adolescence. (Unpublished Master Thesis), Northern Illinois University, Dekalb.

Holmbeck, G. N. (1997). Toward terminological, conceptual, and statistical clarity in the study of mediators and moderators: examples from the child-clinical and pediatric psychology literatures. Journal of Consulting and Clinical Psychology, 65(4), 599.

Hong, F. Y., Chiu, S. I., \& Huang, D. H. (2012). A model of the relationship between psychological characteristics, mobile phone addiction and use of mobile phones by Taiwanese university female students. Computers in Human Behavior, 28(6), 2152-2159.

Jacobsen, W. C., \& Forste, R. (2011). The wired generation: Academic and social outcomes of electronic media use among university students. Cyberpsychology, Behavior, and Social Networking, 14(5), 275-280.

Kahyaoğlu-Süt, H., Kurt, S., Uzal, Ö., \& Özdilek, S. (2016). Efects of smartphone addiction level on social and educational life in health sciences students. Euras Journal Fam Med, 5(1), 13-19.

Kardefelt-Winther, D., 2014. A conceptual and methodological critique of internet addiction research: towards a model of compensatory internet use. Computers in Human Behavior, 31, 351-354.

Kim, S. J., \& Byrne, S. (2011). Conceptualizing personal web usage in work contexts: a preliminary framework. Computers in Human Behavior, 27, 2271-2283.

Kuyucu, M. (2017). Gençlerde akıllı telefon kullanımı ve akıllı telefon bağımlılığı sorunsalı: "akıllı telefon (kolik)" üniversite gençliği [Use of smart phone and problematic of smart phone addiction in young people: "smart phone (colic)" university youth]. Global Media Journal: Turkish Edition, 7(14), 328-359.

King, A. S., Valença, A. M., Silva, A. O., Baczynski, T., Carvalho, M. R., \& Nardi, A. E. (2013). Nomophobia: dependency on virtual environments or social phobia? Computers in Human Behavior, 29(1), 140-144.

Kitamura, T., Kijima, N., Watanabe, K., Takezaki, Y., \& Tanaka, E. (1999). Precedents of percieved social support: Personality and early life experiences. Psychiatry and Clinical Neurosciences, 53, 649-654.

Lee, Y. K., Chang, C. T., Lin, Y., \& Cheng, Z. H. (2014). The dark side of smartphone usage: Psychological traits, compulsive behavior and technostress. Computers in Human Behavior, 31, 373-383.

Lee, J., Cho, B., Kim, Y., \& Noh, J. (2015). Smartphone addiction in university students and its implication for learning. In G. Chen, V. Kumar, Kinshuk, R. Huang, S.C. Kong (Eds), Emerging issues in smart learning (pp. 297-305). Berlin: Springer.

Lemon, J. (2002). Can we call behaviours addictive? Clinical Psychologist, 6, 44-49.

Noyan, C. O., Enez Darçın, A., Nurmedov, S., Yılmaz, O., \& Dilbaz, N. (2015). Akıllı telefon bağımlılığı ölçeğinin kısa formunun üniversite öğrencilerinde Türkçe geçerlilik ve güvenilirlik çalışması [Validity and reliability of the Turkish version of the smartphone addiction scale-short version among university students]. Anadolu Psikiyatri Dergisi [Anatolian Journal of Psychiatry], 16(1), 73-81.

Park, W. (2005). Mobile phone addiction. Mobile Communications, 31, 253-272. 
Park, N., \& Lee, H. (2012). Social implications of smartphone use: Korean college students' smartphone use and psychological well-being. Cyberpsychology, Behavior, and Social Networking, 15(9), 491-497.

Rubin, K. H., Coplan, R. J., \& Bowker, J. C. (2009). Social withdrawal in childhood. Annual review of psychology, 60, 141-171.

Salehan, M., \& Negahban, A. (2013). Social networking on smartphones: When mobile phones become addictive. Computers in Human Behavior, 29(6), 2632-2639.

Samaha, M., \& Hawi, N. S. (2016). Relationships among smartphone addiction, stress, academic performance, and satisfaction with life. Computers in Human Behavior, 57, 321-325.

Sapacz, M., Rockman, G., \& Clark, J. (2016). Are we addicted to our cell phones? Computers in Human Behavior, 57, 153-159.

Seo, D. G., Park, Y., Kim, M. K., \& Park, J. (2016). Mobile phone dependency and its impacts on adolescents' social and academic behaviors. Computers in Human Behavior, 63, 282-292.

Şar, A.H. (2013). Examination of loneliness and mobil phone addiction problem observed in teenagers from some variables. The Journal of Academic Social Science Studies International Journal of Social Science, 6(2). 1207-1220.

Takao, M., Takahashi, S., \& Kitamura, M. (2009). Addictive personality and problematic mobile phone use. CyberPsychology \& Behavior, 12(5), 501-507.

Tan, Ç., Pamuk, M., \& Dönder, A. (2013). Loneliness and mobile phone. Procedia-Social and Behavioral Sciences, 103, 606-611.

Terzi, S. (2008). Üniversite öğrencilerinin psikolojik dayanıklılıkları ile algıladıkları sosyal destek arasındaki ilişki [The relationship between psychological hardiness and social support of university students]. Türk Psikolojik Danisma ve Rehberlik Dergisi [Turkish Psycholohical Counseling and Guidance Assocation], 29, 1-9.

Walsh, S. P., White, K. M., \& Young, R. McD. (2007). Young and connected: psychological influences of mobile phone use amongst Australian youth. In G. Goggin and L. Hjorth (Eds.), Proceedings Mobile Media 2007 (pp. 125-134). University of Sydney.

Whiteside, S. P., \& Lynam, D. R. (2001). The five factor model and impulsivity: Using a structural model of personality to understand impulsivity. Personality and individual differences, 30(4), 669-689.

Yen, J. Y., Yen, C. F., Chen, C. S., Tang, T. C., \& Ko, C. H. (2009). The association between adult ADHD symptoms and internet addiction among college students: the gender difference. Cyberpsychology \& Behavior, 12(2), 187-191.

Yıldırım, İ. (1997). Algılanan sosyal destek ölçeğinin geliştirilmesi, güvenirliği ve geçerliği [The development, reliability and validity of the perceived social support scale]. Hacettepe Üniversitesi Ĕgitim Fakültesi Dergisi [Hacettepe UniversityJournal of Education], 13(13), 8187.

Yılmaz, G., Şar, A.H., \& Şivan, S. (2015). Ergenlerde mobil telefon bağımlı̆̆ı ile sosyal kaygı arasındaki ilişkinin incelenmesi [Investigation of Adolescent Mobile Phone Addiction by Social Anxiety Effect of Some Variable]. Online Journal of Technology Addiction \& Cyberbullying, 2(2), 20-37. 
